\title{
Finding Sustainable Solutions to the Digital Divide in Semi- Urban Honduras
}

\author{
Rodrigo Sarlo \\ Junior, Department of Mechanical Engineering \\ University of Virginia \\ Charlottesville, VA 22904 \\ rs9br@virginia.edu \\ Daniel Saboe \\ Junior, Department of Civil Engineering \\ University of Virginia \\ Charlottesville, VA 22904 \\ djs8d@virginia.edu
}

Abstract - Throughout the developing world unequal levels of access to technology have created a social gap called the digital divide; a considerable disparity in technological opportunities that reinforces social and economic division. A five person student research team from the University of Virginia was assembled to investigate the technological gaps in poor, semi-urban areas of Honduras and to implement a cost-effective, sustainable way to address them. The team used a flexible engineering-based approach to gather and analyze information about community, government, and economic factors relevant to the project, documenting its methodology along the way. The results of the investigation were then tested through the installation of a computer lab for a local school in the community of Las Brisas de la Libertad, in the district of Yoro, Honduras. This paper documents the installation process and describes in detail the considerations needed for its successful and sustainable implementation including community interests, political instability, hardware options, and weather. By analyzing these aspects from their respective advantages and disadvantages, it hopes to serve as a guide for future engineering-oriented service-learning endeavors in international settings.

Index Terms - Computer, Design, Honduras, Internet, Sustainability

INTRODUCTION

Throughout many parts of the developing world unequal levels of access to technology have created a social gap called the digital divide. This is manifested by external divides between the developed and developing world and internal divides between urban and rural areas in individual countries. On an international level this problem can be seen by the fact that $17.5 \%$ of the world's population, primarily in Europe and North America, account for $50 \%$ of the total worldwide internet users ${ }^{\mathrm{i}}$. On a national level, many developing countries have begun to harvest the fruits of the Information Age through the digitization of many aspects of their cultures (commerce, government, and education) in their urban centers. While these countries' urban centers conform to the technological norms of the modern age, many poor, rural villages are left in a cultural isolation. This unequal distribution of technological access creates a drastically different subculture in rural areas with invariably constricted levels of economic opportunity. 
Concerned with the effects of this growing social division, a five person student research team from the University of Virginia was assembled in the spring of 2009 with the purpose of investigating the technological and social gaps in poor, semi-urban areas of Honduras and implementing a cost-effective, sustainable way to address them. The funding for the project came directly from the University's Jefferson Public Citizens (JPC) program in the form of a grant for service-learning research. The in-country component of the project would span twomonths in the summer of 2009.

The team was developed in order to explore technological solutions to the economic stagnation in villages in Honduras. The general research the team did prior to arrival in Honduras led them to believe that a lack of information access was a key factor in Honduran culture that inhibited economic advancement. The teams' understanding of the scope of information access was developed by their own culture's perspective on information, which was centered on internet access. Statistics stating that only $9.09 \%$ of Hondurans use the internet initially led the researchers to the conclusion that a lack of internet connectivity was the primary form in which their evolving notions of the digital divide took ${ }^{\mathrm{ii}}$. Although Honduras is indeed afflicted by the digital divide, the researchers' views on the causes and solutions to this divide transformed after talking directly with several villages in Honduras. For example, interviews in one village revealed that the majority of villagers used cell phones, and a few villagers even had TV's. It was true, the villagers did not have any exposure to the internet, yet they still had a sufficient level of information access so as to not be excluded from local market activities and current events. The student team gradually learned to broaden their own understanding of the scope of information access by learning about the unfamiliar culture before them. Eventually, the authors learned that in some specific cases, the digital divide was perpetuated by a gap in technological exposure in educational systems in urban versus semi-urban settings. This gap translated into a lack of economic opportunities and long-term social exclusion.

The student team learned that when it comes to implementing engineering solutions in unfamiliar cultural settings, one can assume very little. This concern is intensified in unstable environments such as Honduras, a country plagued by economic and political instability. During the two month project, the authors encountered several unforeseen events including a political coup d'etat that immobilized the school system for several days. To be successful in these conditions, an engineering team must start by building a very basic foundation of cultural understanding that will ultimately prove useful when developing a technical design. Success in these situations requires a balance between the simultaneous acquisition of knowledge and its subsequent application in the technical design of a project. This paper aims to expand on this idea by assessing the stumbling points in this project's design process (including the assumptions that led to them) and by detailing how each of the obstacles were addressed from an engineering standpoint. In doing so, it hopes to challenge common student preconceptions and to provide insight on how to develop a more versatile service-learning strategy.

\section{Rationale}

The student team chose to work in the communities surrounding the city of El Progreso, Yoro (the province), since two of the group members had previously visited this city. These members had established connections with representatives of Students Helping Honduras (SHH), an American service organization with a strong presence in the Progreso area. This organization had 
extensive experience working in the region and agreed to be a community partner. This served to provide the team with information and advice as well as to expand the team's local contact base.

Another primary factor in selecting this location was its unique accessibility to both an urban and a rural sector of the Honduran population. This unique attribute can be seen by the fact that the two largest employers for the village in which the team worked were a palm plantation and a Nike apparel factory. The fact that both manufacturing jobs as well as agricultural jobs are located in such close proximity to each other provides significant overlap in the urban and rural economic sectors. The reason this city was so relevant to this investigation was that the commercial nature of the city had created an overwhelming economic and technological disparity between the municipality and the colonias (villages) on its outskirts. These inequalities could be easily noted by the team as they observed the profound gap in the overall quality of houses in close proximity to one another. Animals belonging to poor local farmers graze alongside the wall bordering the city's brand new University; a large, American-style mega-mall stands adjacent to acres of farmland.

The specific village that the team chose to work in was dependent on (1) community willingness to cooperate, (2) the community's specific needs, and (3) the pre-existing infrastructural components of the village (such as electricity and secure buildings). An adequate assessment of these three standards required the allotment of 3 weeks of the project to broadly engaging different communities.

\section{Project Preparation and Design}

Each of the five individuals on the student team possessed unique attributes that would prove useful during the on-site implementation of an engineering solution. Due to fact that most Hondurans do not speak English, it was necessary for the majority of the team members to be fluent in Spanish to allow the team to be independently capable of learning about Honduran culture. Additionally, the team's skill set ( 2 engineering majors, 2 computer science majors, 1 foreign affairs major) made them well suited to provide a technical solution to the digital divide in El Progreso. Also, 2 of the 5 team members had worked in El Progreso before, making logistical planning a more manageable task.

In order to balance the social and technical considerations of the project, the team of 5 was divided up into a "Social Team" and a "Technical Team". The Social Team was responsible for engaging the communities to analyze their needs and to understand their cultures. The Technical team was tasked with finding the most efficient technical solutions, using local equipment and a constrained budget. The two teams worked closely together and consulted one another to create the most balanced solution possible.

In order to provide the team with a sense of direction before arriving in Honduras, the students drafted a pre-arrival design plan that was centered on the connection of computer kiosks to the internet in order to stimulate local economies. However, the team learned that a majority of the assumptions in this pre-arrival design process were based on general data that may not necessarily portray the circumstances in an individual community. The team also realized that it can be especially difficult to account for cultural factors in the planning stages of a project without much prior experience with the culture in question. Generally speaking, the team worked to avoid the structuring of a rigid methodology before being exposed to the work environment. In doing so, the team hoped to make a distinction between the primary goals in the project and 
secondary goals which were willing to be sacrificed. This strategy proved flexible enough to allow the team to adapt the original project idea so that it would coherently incorporate any new knowledge acquired upon arrival in Honduras. Ultimately, the final technical design differed greatly from the original design.

\section{Collecting Information}

One of the first challenges facing the research team was how to successfully collect information about some nearby colonias and their needs. The compiling of this information would go very far in solidifying the project's focus and direction. In the design process, the team identified several options: (1) Speaking with local contacts and members of the town leadership (el patronato), (2) arranging public community meetings, or (3) conducting door-to-door surveys of the community. The first two options, while logistically much easier to undertake, were considered very vulnerable to personal and diplomatic biases ${ }^{\mathrm{iii}}$. As Chambers explains, they would tend to reflect the interests and opinions of the more influential members of the community, namely males and wealthier families ${ }^{\text {iv }}$. Door-to-door surveys, on the other hand, would allow the team to gather information directly from the poorer members of the community who are at many times too alienated and timid to make their voices heard over those with higher status ${ }^{\mathrm{v}}$. This method would entail a time commitment of 1-2 weeks. Two locations were selected as good sources of information: Colonia Las Brisas de la Libertad (referred to as Las Brisas) and Colonia Las Minas (referred to as Las Minas). The team opted for the third investigative method in Las Brisas but was limited to the first and second option in Las Minas due to time constraints.

\section{Cultural Considerations:}

While surveys and interviews are common approaches to collecting information in many cultures in western societies, they are not innate concepts to many Hondurans living in more rural villages. The student team found that door to door questioning, an acceptable and familiar practice for most Americans, creates an uncomfortable situation in the Honduran cultural ethos. Cultural sentiments towards foreigners and the manner in which interviewers often present themselves may make it seem to the interviewees that they are being put in an inferior position ${ }^{\mathrm{vi}}$. Many can feel intimidated and their discomfort can be very counterproductive to conducting surveys. Furthermore, this uneasiness is amplified when dealing with sensitive subjects such education, literacy, and access to technology. For this reason, the surveys had to be refined continuously not only for content but also for methodology. In the end, the team found a casual and informal surveying style to be the most effective. The interviewer would carry on a friendly conversation, trying to eventually lead it to subjects relevant to the project. A recorder would listen and record the information applicable to the survey questions. The questions were simplified and organized in such a way that they could be asked easily and follow the natural flow of a conversation. This process relieved the interviewer from having to take down information, allowing the conversation to progress more freely and sound less mechanical. This in turn created a more relaxed atmosphere for both the interviewers and the interviewees. 


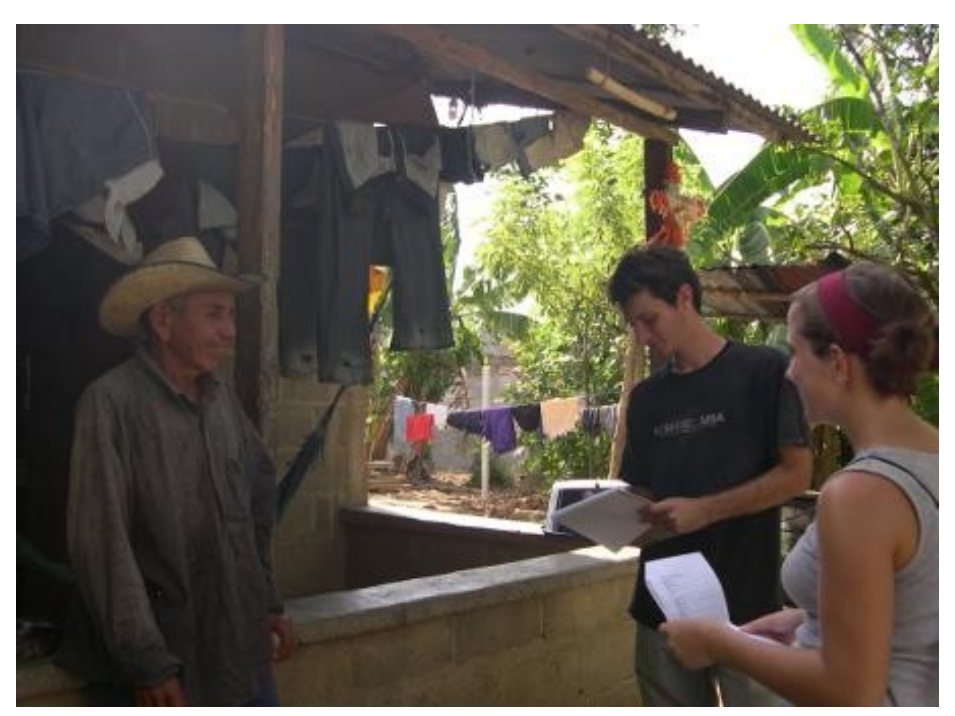

FIGURE 1

SURVEYING PEOPLE IN LAS BRISAS

\section{Technical Considerations:}

The major logistical problem in conducting surveys was how to get a representative sample of the close to 140 households of Las Brisas. An additional consideration was the fact that a majority of the men worked in nearby fields during daytime hours. The team would need to survey in the evenings or weekends if it wished to interview some of the male community members. To make matters more complicated, there was no existing map of the community resulting in a general uncertainty of the layout of the colonia. There was no admittedly easy solution to this dilemma as any method would inevitably miss pieces of information. The team settled for the following methodology:

- $\quad$ First, the entire colonia was scouted to create a street map (Figure 2) which would greatly aid in organizing the survey efforts.

- $\quad$ The map was then divided into seven geographic sections of roughly 20 houses each.

- The team aimed to survey one half of the houses in each section, doing one section per day. This would result in gathering information from about $50 \%$ of households while maintaining a good geographic distribution.

- $\quad$ The team split into groups of two (the minimum needed for one survey) to maximize efficiency. The survey times were varied as much as possible, although surveying in the evening was not done for safety reasons. Surveying on the weekends supplemented the team's inability to survey in the evening.

The surveys spanned a period of 8 days. The team gathered information on 79 households, about $60 \%$ of Las Brisas. The survey results can be seen in Appendix A. 


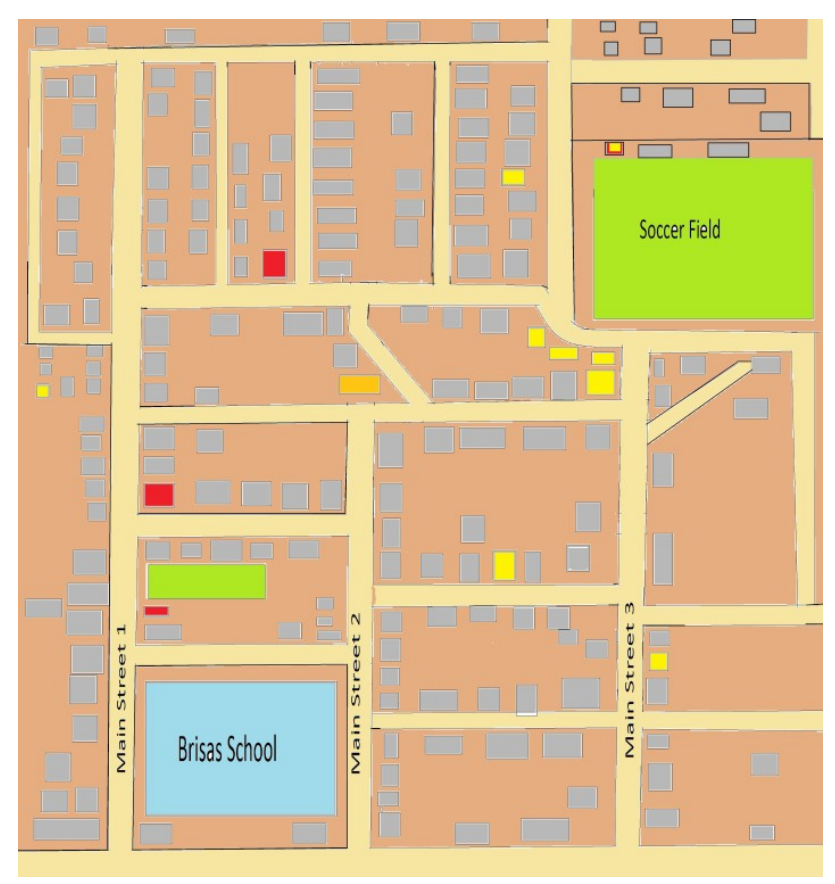

FIGURE 2

STREET MAP OF LAS BRISAS

In order to generate multiple options for implementation, the team explored the viability of a second village located on the outskirts of El Progreso, called Las Minas. With limited man power and a narrow window of time dedicated to community research, the team needed to find a quicker way of gathering information about Las Minas. Meetings were held with the patronato of Las Minas to discuss community concerns, supplemented by guided tours of Las Minas from the back of a pick-up truck. Additionally, two team members were able to attend a major town meeting to speak before a large gathering of the villagers and to listen to their concerns. Although the manner in which information was gathered from Las Minas made the data less quantifiable, it still provided the team with a clear representation of the needs of the community.

\section{Choosing a Plan of Action}

A post-research assessment of two of the primary project sites considered revealed several pros and cons to working in two different villages, Las Brisas and Las Minas. Table I summarizes the infrastructural and economic conditions in the two villages. 
TABLE I

PROJECT SITE ANALYSIS

\begin{tabular}{|c|c|c|c|c|}
\hline Project Site & Infrastructure & Security & Socio-economic & Assessment \\
\hline Las Brisas & $\begin{array}{ll}- & \text { Electricity } \\
- & \text { Secure school } \\
- & \text { Few secure } \\
& \text { public locations }\end{array}$ & $\begin{array}{ll}\text { - } & \text { Many } \\
\text { misdemeanors } \\
\text { - } & \text { Far away, poor } \\
\text { police response. }\end{array}$ & $\begin{array}{ll}\text { - } & \text { Many poor parts, some } \\
\text { middle class. } \\
\text { - }\end{array}$ & $\begin{array}{l}\text { - Could use the school for } \\
\text { security, organization. } \\
\text { - High chance of success } \\
\text { in } 2 \text { months. }\end{array}$ \\
\hline Las Minas & $\begin{array}{ll}- & \text { Electricity } \\
- & \text { Secure school } \\
- & \text { Numerous } \\
& \text { secure public } \\
& \text { locations }\end{array}$ & $\begin{array}{ll}- & \text { Security was still } \\
\text { a concern, but } \\
\text { less of one. } \\
\text { - } \quad \text { Far away, poor } \\
\text { police response. }\end{array}$ & $\begin{array}{ll}- & \text { More wealthy } \\
\text { - } & \text { Very organized } \\
- & 12 \text { computers in local } \\
& \text { school w/ AC } \\
- & \text { No internet at school } \\
- & \text { No artisan skills }\end{array}$ & $\begin{array}{l}\text { - Could connect } \\
\text { computers to internet. } \\
\text { - Would need to teach } \\
\text { adults, artisan/comp. } \\
\text { skills. } \\
\text { - Create kiosk to fund } \\
\text { internet. } \\
\text { - Too little time to } \\
\text { complete in } 2 \text { months. }\end{array}$ \\
\hline
\end{tabular}

Ultimately, the conclusion was reached that where the team worked dictated what the team would do. An engineering solution in Las Minas would look drastically different than the one employed in Las Brisas.

Las Minas already had a strong educational system that included computer education, but they lacked internet access. The team envisioned a technical solution that would connect the computers to the internet so that artisans could sell their products through an online marketplace. Unfortunately, Las Minas is geographically isolated from tourist locations in Honduras, decreasing the financial incentive for villagers to develop artisan skills. As a result, almost none of the villagers already had artisan skills. A combined social and technical solution would involve employing someone to train the villagers to develop artisan skills while the team trained the people to use the internet to become online entrepreneurs. The extensive social mobilization needed to implement a solution in Las Minas could not be compressed into the project timeline. The team underestimated the complexities and long-term nature of a community's required social development in adapting to a new technology.

The team chose to work in Las Brisas, where they felt most confident of implementing a functional solution given the time constraints. Survey results in Las Brisas had revealed that the villagers believed that the main hindrance to economic progress was the unsatisfactory education of the youth. Students who graduated from the primary school rarely progressed to higher education, and found it difficult to obtain higher paying employment. Unless the school's curriculum could adapt to prepare its students to work in a marketplace that is increasingly dependent on computers, the students wouldn't be able to progress economically in society.

Upon consultation with the director of a local primary school in the village, the joint decision was made to install a computer lab in that school in order to expand the economic and educational opportunities that its students have. 


\section{Project Implementation (Computer Lab)}

\section{Technical Considerations:}

A very relevant environmental factor to this project was the hot and humid weather of the Honduran summer. The heat, coupled with the dusty conditions of the Alvaro Contreras School in Las Brisas, created less-than-ideal conditions for the installation of a computer lab. Since computers produce a fair amount of heat, operating them in a hot environment can cause permanent heat damage to the internal circuitry. Furthermore, the dust can accumulate on the hardware and hinder performance.

The team decided that the most effective approach to solving this problem was to visit other computer labs in the area in order to see how this problem was addressed. After looking at several cases, the team found there to be a fairly consistent manner in which schools organized computer labs. In fact, a majority of them were regulated by government guidelines. The common method was the use of an air conditioning/dehumidifying unit installed in an insulated room. While a logical solution, the acclimatization of a room is an expensive process. The cost of AC installation alone amounts to about $\$ 1,000$. In the context of the project's budget, this would mean sacrificing the installation of several computers. Table II lists the advantages and disadvantages associated with the installation of an air conditioning system.

TABLE II

INSTALLING AN AC SYSTEM

\begin{tabular}{|l|ll|}
\hline \multicolumn{1}{|c|}{ Advantages } & \multicolumn{1}{c|}{ Disadvantages } \\
\hline$-\quad \begin{array}{l}\text { Significantly improves computer } \\
\text { lifespan and performance. }\end{array}$ & $-\quad$ Costly, on the order of $\$ 1,000$. \\
- & & $\begin{array}{l}\text { Money could be used to buy additional } \\
\text { computers. } \\
\text { allowing matching public donations. }\end{array}$ \\
$-\begin{array}{l}\text { Creates a more comfortable } \\
\text { environment. }\end{array}$ & $-\begin{array}{l}\text { Places maintenance responsibility on school } \\
\text { staff. }\end{array}$ \\
\hline
\end{tabular}

Due to the fact that new AC units are extremely expensive, the authors decided to investigate the quality and prices of numerous systems at local stores in El Progreso. In order to more fully involve their community partner in the decision making process, and to avoid price gouging, the authors were accompanied by the school director, to each store. Unfortunately, the student team's budget could not cover the cost of a new AC unit. A used AC unit was determined to be the most financially plausible option. The team hired a local mechanic in El Progreso to install the used $\mathrm{AC}$ unit. If the $\mathrm{AC}$ unit were to malfunction, the mechanic would be able to provide a free consultation. Since the used AC unit was only 1 year old, it is not anticipated that major repairs would be needed in the short term. Although the school would not be able to allocate enough money to replace major parts in the AC unit, it does have enough money to pay for minor repairs. 


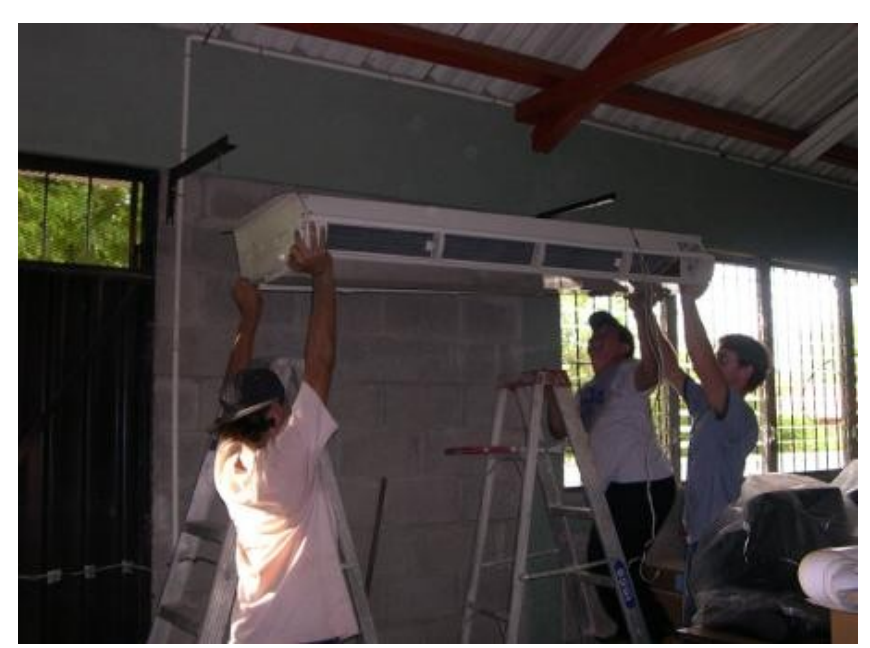

FIGURE 3

Security:

INSTALLING AC

Choosing to install a computer lab in the Centro Básico Alvaro Contreras provided a much more secure environment than the computer kiosk solution would have presented. The school was walled and adequately locked down when the school was not in session, circumventing the necessity of hiring a security guard to keep watch over the computers. It did not mean, however, that the computers were not at risk of being stolen. Theft was not uncommon to the school director, as he mentioned a recent robbery of several electric appliances. The addition of computers to the school would only increase the probability of theft and could potentially endanger the students. In addition, the survey results made it clear that the vast majority of the Las Brisas population (96\%) viewed security as a major problem in their community. After discussing the issue with the school director, Mafo Electronics (a security company), and several members of the community (including the local welder) the team identified five potential security options: (1) Alarm system, (2) electrification of the building housing the computers (suggested by the school's director), (3) reinforced doors, (4) framed computer tables, (5) computer relocation during off-hours. Table III describes and compares the five options. 
TABLE III

SECURITY OPTIONS

\begin{tabular}{|c|c|c|c|c|}
\hline & Description & Advantages & Disadvantages & $\begin{array}{l}\text { Price } \\
\end{array}$ \\
\hline Alarm System & $\begin{array}{l}\text { Simple alarm } \\
\text { system composed } \\
\text { of two door } \\
\text { sensors, a motion } \\
\text { detector, and a } \\
\text { siren. }\end{array}$ & $\begin{array}{l}\text { - Permanent } \\
\text { fixture } \\
\text { - Excellent } \\
\text { intruder } \\
\text { deterrent }\end{array}$ & $\begin{array}{l}\text { - Low probability of } \\
\text { police response } \\
\text { - Susceptible to } \\
\text { tampering }\end{array}$ & $\begin{array}{c}\text { System: } \\
\$ 197.00 \\
\text { Installation Hardware: } \\
\$ 29.00\end{array}$ \\
\hline $\begin{array}{c}\text { Building } \\
\text { Electrification }\end{array}$ & $\begin{array}{l}\text { Entails passing an } \\
\text { electric current } \\
\text { through the } \\
\text { building to shock } \\
\text { any potential } \\
\text { intruders that touch } \\
\text { the metal doors or } \\
\text { windows. }\end{array}$ & $\begin{array}{l}\text { - Very high level } \\
\text { of security } \\
\text { - Low cost }\end{array}$ & \begin{tabular}{l|} 
- Extremely \\
dangerous, \\
especially around \\
children \\
- No clear method for \\
installation or \\
regulation
\end{tabular} & $\begin{array}{l}\text { Installation: } \\
\quad \$ 10.00\end{array}$ \\
\hline $\begin{array}{l}\text { Reinforced } \\
\text { Doors }\end{array}$ & $\begin{array}{l}\text { Added layer of } \\
\text { double doors with } \\
\text { reinforced locks }\end{array}$ & $\begin{array}{l}\text { - Permanent } \\
\text { Fixture } \\
\text { - Most basic way } \\
\text { to prevent } \\
\text { forced entrance } \\
\end{array}$ & $\begin{array}{l}\text { - High cost } \\
\text { - 3-day installation } \\
\text { period }\end{array}$ & $\begin{array}{r}\text { Materials: } \\
\$ 286.00 \\
\text { Installation: } \\
\$ 108.00\end{array}$ \\
\hline $\begin{array}{l}\text { Computer } \\
\text { Frames }\end{array}$ & $\begin{array}{l}\text { Tables with a } \\
\text { frame that encloses } \\
\text { the monitor and } \\
\text { CPU preventing } \\
\text { their removal }\end{array}$ & $\begin{array}{l}\text { - Permanent } \\
\text { fixture } \\
\text { - Good back-up } \\
\text { measure in the } \\
\text { case of forced } \\
\text { entrance }\end{array}$ & $\begin{array}{l}\text { - High cost } \\
\text { - 2-day installation } \\
\text { period for two } \\
\text { frames } \\
\text { - Uncomfortable for } \\
\text { computer use }\end{array}$ & $\begin{array}{c}\text { Materials: } \\
\$ 135.00 \\
\text { Installation } \\
\$ 108.00 \\
\text { (costs of } 2 \text { frames) }\end{array}$ \\
\hline $\begin{array}{l}\text { Computer } \\
\text { Relocation }\end{array}$ & $\begin{array}{l}\text { Entails relocating } \\
\text { computers to a } \\
\text { safer location when } \\
\text { school is not in } \\
\text { session }\end{array}$ & $\begin{array}{l}\text { - No cost } \\
\text { - Significantly } \\
\text { reduces risk of } \\
\text { theft }\end{array}$ & $\begin{array}{l}\text { - Time consuming } \\
\text { - Impractical }\end{array}$ & $\mathrm{N} / \mathrm{A}$ \\
\hline
\end{tabular}

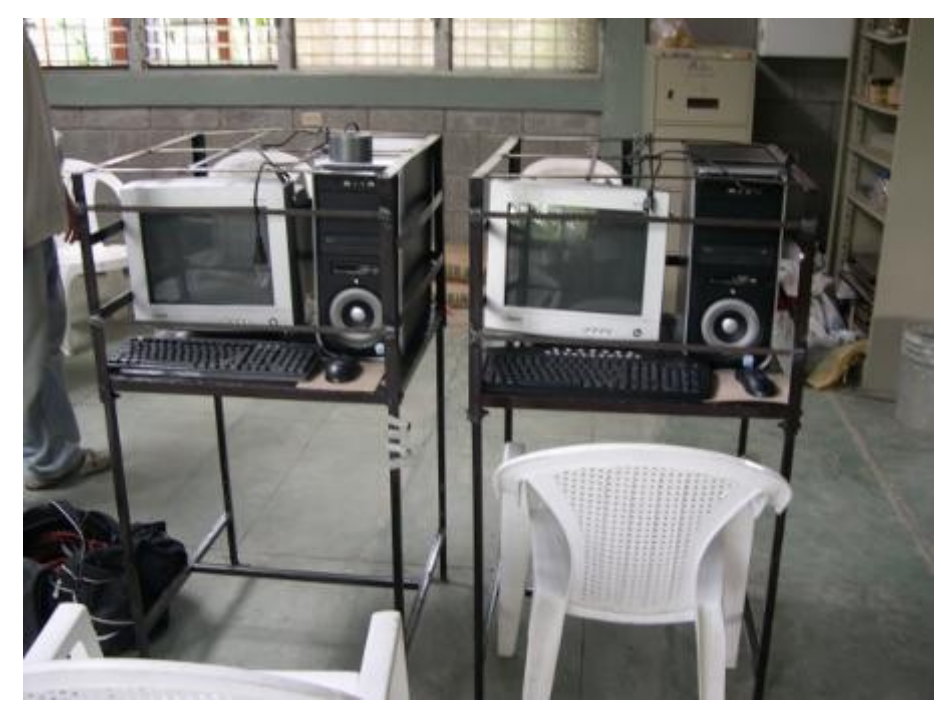

FIGURE 4 
The building's electrification was rejected based on the very probable risk of a child's electrocution in the event that the system was not turned off properly. The relocation option was deemed much too impractical to be implemented. After careful deliberation and a general unwillingness to sacrifice the security of the project, the team decided upon combining options 1, 3, 4: an alarm-based system coupled with reinforced building doors and protective frames for the computers. This would provide a reasonably high level of security without the need for monthly fees or the endangerment of the school's students.

The alarm system, consisting of a motion sensor and two door sensors, was purchased in the neighboring city of San Pedro Sula for a price of $\$ 196.76$. The installation was done completely by the research team to offset installation costs. This included the physical installation (wiring, drilling, etc.) as well as the alarm programming. The system was tested several times to ensure functionality. The alarm would serve primarily as a scare tactic, since the lack of a local police station as well as general police unreliability made it improbable that there would be a response in the event of a break in.

One of the local welders was commissioned both to reinforce the doors and build the computer frames. Rather than modify the two existing doors, it was decided to protect them with a new set of stronger welded-iron doors. The final cost, installation costs included, for the two welded-iron double doors was $\$ 394.60$. The frames were constructed of the same material as the doors, forming a roughly $1 \mathrm{~m} \times 1.5 \mathrm{~m} \times 1.7 \mathrm{~m}$ cage around the computer with enough space to operate the mouse and keyboard comfortably but not enough to remove the monitor or CPU. The frames, work included, cost $\$ 121.63$ each. Due to this high cost, the team opted only to install them for the two pricier clone computers (explained in the Hardware and Software section below).

\section{Hardware/Software:}

The success of this project depended largely on the cost-effective use of hardware (i.e. computers and accessories) and software (i.e. operating systems and programs). The efficient use of funds when purchasing these elements would mean more computers for the students and teachers of C.E.B. Alvaro Contreras, thereby optimizing their educational opportunities. During the design phase, the team opted to purchase desktop computers locally rather than transporting them from the United States. Aside from being much more practical, this method avoided burdensome shipping costs, allowed for warranties and customer service on the purchased computers, and also supported the local economy. This limited the project scope to two sets of options:

- Clone or refurbished desktop computers (hardware)

- open source versus closed source programs (software)

In the context of software, the team faced a typical decision encountered by most computer-

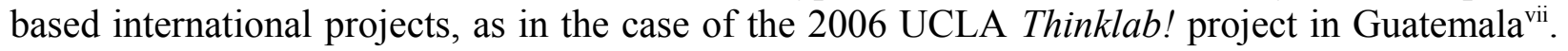
Linux is the traditional choice for open source, Windows the traditional choice for closed source. The decision between the two is generally a difficult one, since both have very distinct advantages. Table IV outlines a general analysis of the characteristics of the two options. 


\section{TABLE IV}

ANALYSIS OF HARDWARE/SOFTWARE OPTIONS

\begin{tabular}{|c|c|c|}
\hline \multicolumn{3}{|c|}{ Hardware } \\
\hline Type & Advantages & Disadvantages \\
\hline Clone Computer & $\begin{array}{l}\text { - More reliable/durable } \\
\text { - Computers are new } \\
\text { - Includes Widows OS as well as } \\
\text { Windows Office package (Spanish) } \\
\end{array}$ & $\begin{array}{l}\text { - Higher cost } \\
\text { - No brand name }\end{array}$ \\
\hline Refurbished Computers & $\begin{array}{l}\text { - Lower cost } \\
\text { - Brand name } \\
\text { - Includes Windows OS (English) }\end{array}$ & $\begin{array}{l}\text { - Less reliable } \\
\text { - Computers are previously used } \\
\text { - Does not include Windows Office } \\
\text { Package }\end{array}$ \\
\hline \multicolumn{3}{|c|}{ Software } \\
\hline Open Source & $\begin{array}{l}\text { - Free of cost } \\
\text { - Source code is visible } \\
\text { - Creative and flexible } \\
\text { - More powerful networking tool } \\
\text { - Easy to transfer skills to closed source }\end{array}$ & $\begin{array}{l}\text { - Not a familiar type of software } \\
\text { - No support network } \\
\text { - Skills not required for most jobs }\end{array}$ \\
\hline Closed Source & $\begin{array}{l}\text { - The standard software required for most } \\
\text { job positions } \\
\text { - Support network/customer service } \\
\text { - Familiar software }\end{array}$ & $\begin{array}{l}\text { - Licensing fees required } \\
\text { - Source code unavailable } \\
\text { - Less flexible }\end{array}$ \\
\hline
\end{tabular}

The team began by buying two clone computers at the suggestion of computer engineering faculty from the local university, Univesidad Tecnológica de Honduras (UTH), a potential community partner. These computers came equipped with the Microsoft Widows operating system as well as the Windows Office package, eliminating the need to choose between open and closed source. The closed source programs were added for completeness. The team also decided to purchase refurbished computers to compare their performance and, finding them satisfactory, decided to use this option for future purchases. The decision was based on the following: (1) the refurbished computer were of comparable quality to the clones, (2) were significantly cheaper (Clone: \$452.00; Refurbished: \$135.00) and (3) still came with a warranty. The refurbished computers, however, did not include the Microsoft Office package. The team opted for open source software (Linux Open Office) on these, believing that the Windows Office programs on the clone computers would provide adequate exposure for employment purposes to teachers and students.

\section{Internet:}

The installation of internet was the culminating goal of the project, since the team considered it to be the most important tool for improving educational opportunities. The poor sectors of most developing countries, however, suffer from an inadequate telecommunication infrastructure, making a wired wire internet connection a nonviable solution ${ }^{\text {viii. }}$. Many service programs, such as the 1997 Word Links pilot project have dealt with this issue by employing the use of cellular connections ${ }^{\mathrm{ix}}$.

The team found that they could address this problem in the same fashion through the use of portable cellular computer modems. These are USB devices that connect to the internet via cellular telephone signals. These devices can be used anywhere that has cell phone reception. 
The connection could also be distributed among several computers, although the connection speed would significantly decrease for every computer connected to the modem. The major drawback was that, while Las Brisas had cell phone reception, it was not within range of a 3G connection. This meant that modems were limited to a $128 \mathrm{Kbps}$ connection, only enough to send emails and surf the web. For this reason, connection distribution was generally not used, since it led to an impractically low speed. In order to maintain the internet connection, $\$ 15$ a month of project funds were required.

\section{Involving The Community Partner:}

Throughout the installation of all components of the project's technical design, the team consulted the primary school's staff in order to identify which specific technical components would best serve them. The teachers indicated that they wanted to be trained how to use Open Office programs to type and format worksheets, as well as how to use spread sheets to calculate student averages. In addition to printing these documents, the teachers wanted to learn how to make copies of pages in textbooks so that they could provide students with additional resources. They also were very interested in learning how to use the internet to find visual aids. In an underfunded school where not every student is guaranteed a textbook, the ability to use the internet to acquire supplementary material can drastically improve the educational experience of the school's students.

\section{Final Product:}

The completed C.E.B. Alvaro Contreras computer lab consisted of:

- 9 computers (2 clone, 7 refurbished)

- 1 printer/copier

- 2 portable cellular modems

- a customized security system (2 reinforced double doors and an alarm system)

- 1 air conditioning unit

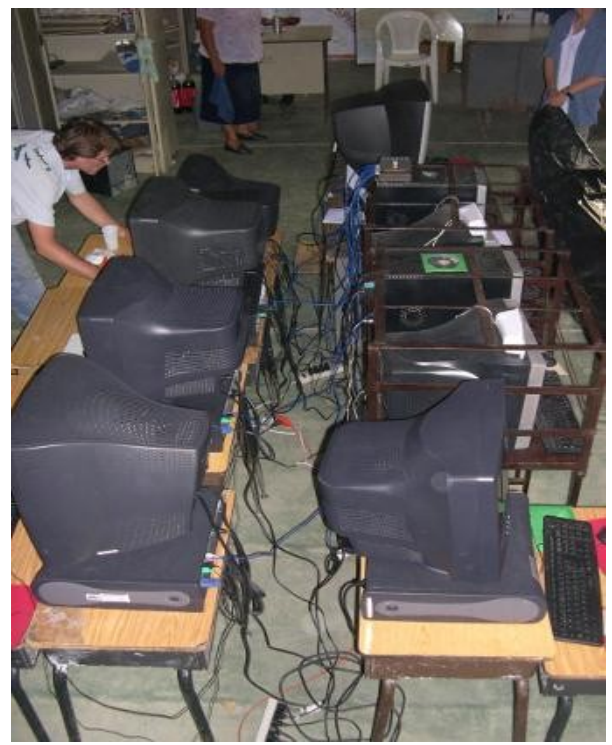

FIGURE 6

FINALIZED COMPUTER LAB 


\section{Project Maintenance and Sustainability}

\section{Project Goals for a Sustainable System:}

During the second month of on-site work, the team focused on partnering with pre-existing community institutions, adapting the technical design to ensure community buy-in, promoting functionality between the project's technical and social spheres, and creating a mechanism for financial/technical sustainability.

Specifically, these project goals needed to ensure:

- There is a sense of ownership between a community partner and the project.

- The end result of the project helped to bridge the digital divide between Las Brisas and El Progreso.

- A mechanism is in place to promote the efficient education of the students in Las Brisas.

- The community partner must be capable of troubleshooting and dealing with hardware maintenance issues related to the computer lab.

- The school would have the resources it needed to pay for repairs when the computers' 1-year warranties expired, and monthly internet fees.

This ambitious, specific definition of a sustainable computer lab would meet classroom expectations for an engineering student, however, the actual realization of this definition proved incredibly difficult, given the time constraints and the unstable nature of many elements of Honduran culture.

\section{Partnership with Pre-existing Community Structure:}

From the onset of this project, attempts were made to involve the local community college, UTH, in the project. A partnership with this pre-existing community member would provide technical support after the team left Honduras. However, many UTH students were unwilling to partner with the engineering team due to the fact the majority of students also worked part time to defray their educational costs. Additionally, strong initial staff support for the project died out after a change in the university administration. Even UTH, a seemingly stable, public college was not as sustainable as it seemed.

Recognizing the importance of long-term maintenance of the project the team turned its attention to the director of the Las Brisas school. In the last weeks of implementation, the team began a transition in project responsibilities to give him control of the project. This put him in the position of a boss rather than a community gatekeeper. Simple steps were taken to foster this transition in ownership, such as allowing the director to turn off computers, cover them with tarps, arm the alarm system prior to leaving, and lock up the entire computer lab. The team members began consulting him with respect to the budget as well, by presenting him with options and seeking his advice. This mutual trust and exciting new opportunity for the school may have been what prompted the school to remain open to students when all the other teachers in the area went on strike during the political crisis. 


\section{Community Buy-In:}

An engineering project that does not take into account the individual needs of all involved stakeholders has failed. It is important to understand that the needs of the stakeholders are frequently competing. For the authors' computer education project in Las Brisas, there were numerous stakeholders, each with their own agenda. Table $\mathrm{V}$ shows a list of the different needs of the various stakeholders and how those needs were addressed.

\section{TABLE V}

\section{COMMUNITY BUY-IN}

\begin{tabular}{|c|c|c|c|c|c|}
\hline Stakeholder & Students & Parents & Teachers & Director & Gangs \\
\hline Need & $\begin{array}{c}\text {-Want } \\
\text { computers to } \\
\text { be fun. }\end{array}$ & $\begin{array}{c}\text {-Want kids to } \\
\text { learn computer } \\
\text { skills. }\end{array}$ & $\begin{array}{c}\text {-Want to use } \\
\text { computers for } \\
\text { quizzes, grades. }\end{array}$ & $\begin{array}{c}\text {-Wanted to see long } \\
\text { term survival of } \\
\text { lab. }\end{array}$ & $\begin{array}{c}\text {-Were a threat to the } \\
\text { security of the lab. }\end{array}$ \\
\hline $\begin{array}{c}\text { Balanced } \\
\text { Solution } \\
\text { pastalled } \\
\text { pario, } \\
\text { patected user } \\
\text { accounts }\end{array}$ & $\begin{array}{c}\text { Rotating comp. } \\
\text { class for } \\
\text { students. }\end{array}$ & $\begin{array}{c}\text { Bought computer, } \\
\text { scanner, copier. } \\
\text { Trained teachers to } \\
\text { use excel. }\end{array}$ & $\begin{array}{c}\text { Installed AC to } \\
\text { increase comp. } \\
\text { service lifetime. }\end{array}$ & $\begin{array}{c}\text { Employed a multi-faceted } \\
\text { security system. }\end{array}$ & \\
\hline
\end{tabular}

An analysis of the proposed technical design shows how all stakeholders' needs in the project were addressed on some level. The technical design could theoretically function; however, it would be dependent on the degree to which the technical design could conform to the preexisting social conditions in the village.

\section{Social Sustainability:}

In order to become capable computer education instructors, the primary school teachers, needed to be computer literate. This meant that 9 teachers had to be trained in 4 weeks, 6 of whom had no extensive knowledge of computers. In the month remaining after implementation, the teachers participated in a 20-hour computer literacy course that was taught by the engineering team. This course covered the basics of interface control, typing, hardware usage, Microsoft office, and educational freeware programs. Additionally, after 2 computers were connected to the internet, the teachers were taught the basics of web navigation. By the end of this course, teachers who had never used computers before were capable of creating and printing tests on the computers. Others were using Microsoft excel formulae to calculate averages for their students. Hardware maintenance and troubleshooting procedures were explained to the teachers. Although the learning process did not stop at the end of the 20-hour course, the teachers had enough knowledge to begin instructing the kids after the team left Honduras. Within 2 weeks of leaving Honduras, the engineering team received an email from the teachers from the computer lab informing them that they had implemented a rotating schedule for the kids to begin learning. Throughout the standard school year, students in grades 3-8 continue to rotate into the computer lab with their teachers for an hour each day per class. 


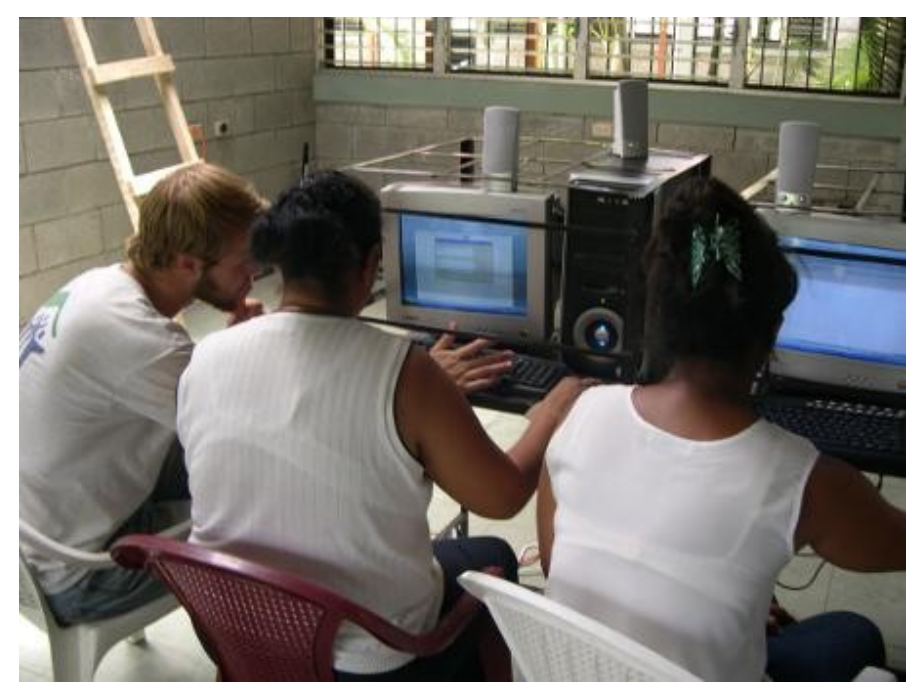

FIGURE 7

TEACHING A COMPUTER LITERCAY COURSE

\section{Financial/Technical Sustainability:}

The intensive education of the teachers appeared to have paid off; however, this investment would only last as long as the computers themselves. The computers all had a 1-year guarantee from the store where they were purchased. After this year, a malfunctioning computer would need to be repaired or replaced at the expense of the school. In order to promote financial sustainability, the engineering team attempted to create a revenue generation model for the school using computer education of adults in Las Brisas for profit for the school. This would in essence, create a social business that would raise funds to pay for internet and repairs for the computer lab.

Even though the creation of a system for financial sustainability did not seem possible in the remaining 2 weeks in Honduras, the options seemed few, so the student team began the initial steps through door-to-door interviews in Las Brisas to begin recruiting for a paid, adult computer literacy class. Although the director of the school supported the idea for a social business, he did not approve of the timing on account of the insufficient practice his teachers had received with the computers. Additionally, the director felt that the final recruitment of an adult class would need to be approved by him, in order to prevent untrustworthy individuals in the village from entering the school. He halted the recruitment process indefinitely until he felt that his teachers were more capable of teaching classes to adults.

The lesson learned was that the progress of an engineering project is ultimately governed by the evolution of the community's readiness to accept it, if at all, not by the engineers' own ambitious project timeline. Although financial sustainability was not explicitly achieved prior to the engineers' departure, a potential longer-term option was presented to the director, who would eventually have the choice to pursue it or to find an appropriate alternative.

\section{CONCLUSIONS}

The engineering student team set out with the intention of implementing an engineering solution that would address some of the economic problems associated with the digital divide in El 
Progreso, Honduras. In doing so, the team learned that vastly different approaches are necessary in drafting technical designs in foreign cultures than for traditional engineering methodology in familiar cultural settings.

When engineers intend to implement a project in an unfamiliar cultural setting, they must understand the critical interplay between their technical design and the culture in question by realizing that their technical knowledge is only one of the two variables necessary to formulate a solution. It is equally important to understand that the engineer's technical design is a new variable that must conform to the pre-existing, unknown cultural variable. Necessarily, the project must include an investigative phase in which the engineers identify and define the unknown, cultural variables that will influence their project's success or failure. After the relevant cultural considerations are understood, the engineer may subsequently introduce their technical solution appropriately in order to balance the equation and solve the original problem.

In unknown cultural settings, the technical design must evolve in unison with the engineer's progressive understanding of the new culture. This evolving technical design invariably requires the engineers to have flexible timelines, budgets, technical strategies, and personal attitudes throughout the implementation phase of the project. The best way to achieve this level of flexibility is to involve a pre-existing social system as an equal, partner throughout the implementation of the project. This will provide a high degree of support from a partner that understands the culture in question. This partnership will also provide a more established sense of project ownership that will continue to guide the project's success after the engineer's departure following the project's technical implementation.

\section{APPENDIX A: Survey Statistics}

Joint UVA/SHH teams surveyed seventy-nine households in Las Brisas from June 6-18, 2009. Households often included multiple families and domiciles, and probably constitute well over half of the estimated 140 houses in the community.

\begin{tabular}{|c|c|c|}
\hline Parameter & Percentage & No. of Respondents \\
\hline Adult Literacy Estimate & $70.6 \%$ & 125 of 177 \\
\hline Families with Children & $87.3 \%$ & - \\
\hline School Attendance & $79.3 \%$ & - \\
\hline High-School Attendance & $36.4 \%$ & 12 of 33 \\
of males & $26.7 \%$ & 4 of 15 \\
of females & $44.4 \%$ & 8 of 18 \\
\hline Safety Concerns & $96.2 \%$ & 76 of 79 \\
\hline Education Concerns & $48.1 \%$ & 38 of 79 \\
\hline Market Concerns & $20.2 \%$ & 16 of 79 \\
\hline Healthcare Concerns & $2.5 \%$ & 2 of 79 \\
\hline \multicolumn{2}{|c|}{ For Children } \\
\hline English-learning \#1 priority & $71.4 \%$ & 45 of 63 \\
\hline Computer-learning \#1 priority & $19.0 \%$ & 12 of 63 \\
\hline Remediation \#1 priority & $9.5 \%$ & 6 of 63 \\
\hline \multicolumn{2}{|c|}{ For Adults } \\
\hline English-learning \#1 priority & $71.7 \%$ & 43 of 60 \\
\hline Computer-learning \#1 priority & $23.3 \%$ & 14 of 60 \\
\hline Remediation \#1 priority & $5.0 \%$ & 3 of 60 \\
\hline
\end{tabular}


International Journal for Service Learning in Engineering

Vol. 5, No. 1, pp. 170-188, Spring 2010

ISSN 1555-9033

\section{Acknowledgment}

The authors would like to thank the Jefferson's Public Citizens Program for providing the student team with the resources to conduct this project. Also, they would like to thank their faculty advisor, Professor Robert Swap (University of Virginia), for his enormous support throughout the course of the project. 
International Journal for Service Learning in Engineering

Vol. 5, No. 1, pp. 170-188, Spring 2010

ISSN 1555-9033

\section{References}

'Wunnava, Phanindra; Leiter, Daniel, "Determinats of Inter-Country Internet Diffusion Rates," Institute for the Study of Labor (2008)

ii World Bank, "Internet Users as Percentage of Population." 2008

iii Chambers, Robert. Rural Development. (Halsted Press, 1983), 13-22.

iv Chambers, Robert. Rural Development 13-22

${ }^{v}$ Chambers, Robert. Rural Developmen. 13-22

${ }^{v i}$ Chambers, Robert. Rural Development, 22

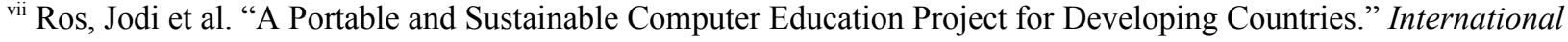
Journal for Service Learning in Engineering 1, no. 1 (2006): 27-28.

viii Hawkins, Robert. "Ten Lessons for ICT and Education in the Developing World.” World Bank Institute (2002): 40.

ix Hawkins, Robert. "Ten Lessons for ICT and Education in the Developing World." 40 